\title{
CORPORATE SOCIAL RESPONSIBILITY DAN LEVERAGE MENDORONG TERJADINYA AGRESIVITAS PAJAK
}

\author{
Febi Ayu Pujiarti ${ }^{1}$, Hetti Herawati ${ }^{2}$ \\ ${ }^{1,2}$ Universitas Sangga Buana YPKP Bandung \\ ${ }^{1}$ korespondensi : febiayupuji@gmail.com
}

\begin{abstract}
ABSTRAK
Tax aggressiveness is an effort made by the company with the aim of minimizing tax payments. This study aims to determine and describe how much Corporate Social Responsibility and leverage can encourage tax aggressiveness. The population in this study are transportation companies listed on the Indonesia Stock Exchange during 2017-2019. The sampling technique used purposive sampling method which resulted in 33 companies. The type of research data is panel data, with research data sources using secondary data from transportation companies listed on the Indonesia Stock Exchange. The analytical method used in this research is descriptive statistical analysis and regression analysis. The results showed that Corporate Social Responsibility had no effect on tax aggressiveness while leverage had an effect on tax aggressiveness.
\end{abstract}

Keywords: Corporate Social Responsibility, CSR, Leverage, Tax aggressiveness.

\begin{abstract}
ABSTRAK
Agresivitas pajak merupakan suatu upaya yang dilakukan perusahaan dengan tujuan untuk meminimalisir pembayaran pajak. Penelitian ini bertujuan untuk mengetahui dan mendeskripsikan seberapa besar Corporate Social Responsibility dan leverage dapat mendorong terjadinya agresivitas pajak. Populasi dalam penelitian ini adalah perusahaan transportasi yang terdaftar di Bursa Efek Indonesia selama tahun 2017-2019. Teknik pengambilan sampel menggunakan metode purposive sampling yang menghasilkan 33 perusahaan. Jenis data penelitian merupakan data panel, dengan sumber data penelitian menggunakan data sekunder dari perusahaan transportasi yang terdaftar di Bursa Efek Indonesia. Metode analisis yang digunakan dalam penelitian ini adalah analisis statistik deskriptif dan analisis regresi. Hasil penelitian menunjukan bahwa Corporate Social Responsibility tidak berpengaruh terhadap agresivitas pajak sedangkan leverage berpengaruh terhadap agresivitas pajak.
\end{abstract}

Kata Kunci: Corporate Social Responsibility, CSR, Leverage, Agresivitas Pajak.

\section{PENDAHULUAN}

Pajak merupakan salah satu sektor yang berkontribusi bagi pendapatan negara dalam membiayai Anggaran Pendapatan dan Belanja Negara (APBN), dengan kontribusi mencapai $85,65 \%$ dari keseluruhan penerimaan negara (Kompas.com), dengan demikian dapat dipastikan bahwa pajak mempunyai peran yang sangat penting dalam mendukung keuangan negara.

Agresivitas pajak merupakan salah satu faktor yang dinilai sebagai salah satu penyebab tidak teralisasinya target penerimaan pajak. Melalui perencanaan pajak maka pajak dapat ditekan secara optimal dengan cara legal (Bardjo Sugeng).

Agresivitas pajak terjadi karena ada perbedaan sudut pandang antara perusahaan dengan fiskus. Bagi pemerintah, pajak merupakan sumber pendapatan, sedangkan bagi perusahaan, pajak merupakan beban yang akan mengurangi laba perusahaan. Jika pendapatan perusahaan semakin besar, maka akan semakin besar pula beban pajak yang harus dibayarkan perusahaan. Berkenaan dengan itu, berbagai cara diupayakan perusahaan untuk meminimalisir pajak dengan cara yang legal. Indikasi terjadinya agresivitas pajak yang dilakukan oleh perusahaan dapat 
dilihat dari bagaimana tanggung jawab perusahaan terhadap ruang lingkup internal maupun eksternalnya.

Corporate social responsibility (CSR) merupakan pendekatan bisnis dengan memberikan kontribusi terhadap pembangunan yang berkelanjutan dengan memberikan manfaat ekonomi, sosial dan lingkungan bagi seluruh pemangku kepentingan. CSR mendorong perusahaan untuk peduli pada lingkungan sekitar dan untuk membangun komunikasi dengan lingkungan. Program tersebut membuat masyarakat merasa nyaman dan merasa dihargai hak haknya. Hal tersebut menunjukkan adanya simbiosis mutualisma antara perusahaan dan masyarakat, untuk itu citra perusahaanpun akan terangkat secara otomatis.

Dalam Undang-undang Nomor 36 Tahun 2008 tentang Pajak Penghasilan, kegiatan CSR dapat menjadi tax deductible untuk jenis kegiatan tertentu.

Disamping CSR, Leveragepun merupakan akun yang jadi pertimbangan manajemen untuk jadi bagian dari agresivitas pajak. Leverage adalah tingkat hutang perusahaan untuk membiayai aktivitas operasinya. Leverage seringkali digunakan untuk menutupi kebutuhan dana perusahaan yang bertujuan untuk meningkatkan laba atau melakukan ekspansi. Leverage menjadi pilihan bagi perusahaan karena leverage menimbulkan beban bunga yang nantinya akan menjadi beban perusahaan dan otomatis mengurangi laba perusahaan. Semakin tinggi tingkat utang perusahaan, maka semakin tinggi indikasi perusahaan tersebut melakukan tindakan agresivitas pajak [1].

\section{TINJAUAN PUSTAKA}

\section{Agresivitas Pajak}

Sebagai fungsi budgeter pajak mempunyai peran penting atas kontribusinya pada APBN, untuk itu pemerintah terus berupaya menggerakan masyarakat untuk memenuhi kewajiban perpajakan, sesuai dengan isi undang-undang No 28 Tahun 2007 tentang Ketentuan dan Tata Cara Perpajakan Pasal 1(1), pajak didefinisikan sebagai kewajiban yang harus dilakukan baik oleh orang pribadi maupun badan yang bersifat memaksa berdasarkan undang-undang dengan tidak mendapatkan imbalan secara langsung dan digunakan untuk kepentingan negara dan sebesar-besarnya untuk kemakmuran rakyat.

Seiring dengan definisi tersebut, pemerintah terus berupaya melakukan regulasi perpajakan yang diharapkan akan mampu meningkatkan realisasi penerimaan pajak.

Bedanya sudut pandang antara perusahaan dan pemerintah (fiscus) telah mendorong tindakan perencanaan pajak atau agresivitas pajak yang diharapkan dapat meminimalisir pajak yang terhutang.

"Perencanaan Pajak adalah proses mengorganisasikan usaha wajib pajak atau sekelompok Wajib Pajak sedemikian rupa sehingga utang pajaknya, baik pajak penghasilan maupun pajak-pajak lainnya, berada dalam posisi yang serendah mungkin, sepanjang hal ini dimungkinkan baik oleh ketentuan peraturan perundang-undangan perpajakan maupun secara komersial." [2].

Agresivitas pajak adalah kegiatan merekayasa pendapatan kena pajak melalui tindakan 
perencanaan pajak baik secara legal maupun illegal [3]. Agresivitas pajak adalah kegiatan yang dilakukan dengan sengaja oleh manajemen perusahaan yang bertujuan untuk menekan beban pajak perusahaan agar laba perusahaan dapat dimaksimalkan. Agresivitas pajak sebagai keinginan perusahaan untuk meminimalisir beban pajak dengan tax planning secara legal, ilegal maupun keduanya dan bertujuan memaksimalkan nilai perusahaan [4].

Agresivitas pajak dapat didefinisikan sebagai segala upaya yang diakukan oleh manajemen untuk menurunkan jumlah beban pajak dari yang seharusnya dibayar oleh perusahaan [5]. Agresivitas pajak merupakan bagian dari manajemen pajak dalam hal perencanaan pajak yang dilakukan oleh perusahaan dalam usaha mengurangi tingkat pajak [6]. Pengukuran tingkat agresivitas pajak akan menggunakan proksi ETR (Effective Tax Rate) dimana semakin rendahnya nilai ETR akan menggambarkan tingginya tingkat agresivitas pajak. Sebaliknya jika nilai ETR semakin tinggi maka akan menggambarkan semakin rendahnya tingkat agresivitas pajak [7] dengan rumus :

$\mathrm{ETR}=\frac{\text { Beban Pajak Penghasilan }}{\text { Laba Sebelum Pajak }}$

Banyak cara dan teknik yang dilakukan dalam aktivitas perencanaan pajak, termasuk perkiraan perikraan yang dipandang memiliki potensi untuk meminimalisir pajak, seperti CSR dan Leverege.

\section{Corporate Social Responsibility}

Corporate Social Responsibility pertama kali dikemukakan oleh Howard B pada Tahun 1953 dalam bukunya "The Social Responsibilities of A Businessman" mengungkapkan bahwa: Corporate Social Responsibility (CSR) adalah sebuah komitmen bisnis yang berkontribusi pada pembangunan ekonomi yang berkelanjutan sekaligus meningkatkan kualitas hidup para karyawan, komunitas lokal, masyarakat dan keluarganya. Menurut Rudito \& Famiola (2013:103) CSR adalah tindakan dalam mengelola biaya yang dikeluarkan maupun keuntungan yang telah didapatkan perusahaan dengan tujuan memberikan dampak positif bagi lingkungan serta masyarakat luas.

Untuk pengukuran pengungkapan CSR menggunakan indikator Global Reporting Initiative (GRI) versi G4 dengan total item pengungkapan sebanyak 91 item, dengan rumus [8]:

$\mathrm{CSR}_{\mathrm{i}}=\frac{\text { Item } C S R \text { yang diungkapkan }}{91 \text { item pengungkapan } G R I G 4}$.

\section{Leverage}

Leverage adalah rasio yang digunakan dalam mengukur sejauh mana aktiva perusahaan dibiayai oleh hutang, dimana artinya seberapa besar beban utang yang ditanggung perusahaan dibandingkan dengan aktivanya [9]. Leverage menjadi sumber pendanaan perusahaan untuk membayar kewajibannya baik jangka panjang maupun jangka pendek yang diperoleh dari pihak eksternal. Hal tersebut menegaskan bahwa leverage adalah kemampuan optimalisasi sumber dana yang diperoleh dari utang untuk kebutuhan operasional perusahaan. 
Pengukuran leverage akan dilakukan dengan menggunakan rasio DAR (Debt to Asset Ratio) yang merupakan perbandingan antara total utang dengan total aset. Rumus DAR [9] sebagai berikut:

DAR $=\frac{\text { Total Utang }}{\text { Total Aset }}$

\section{Teori Legitimasi}

Teori legitimasi merupakan sistem pengelolaan perusahaan yang berorientasi pada keberpihakan terhadap masyarakat, pemerintah, individu dan kelompok masyarakat [10]. Teori tersebut menjelaskan bahwa pengungkapan tanggung jawab sosial yang dilakukan perusahaan, pada dasarnya adalah untuk mendapatkan legitimasi dari masyarakat dimana perusahaan berada. Legitimasi ini penting, untuk menjaga perusahaan agar terhindar dari hal-hal yang tidak diinginkan dan dapat meningkatkan nilai perusahaan

\section{Teori Stakeholder}

Teori stakeholder memprediksi manajemen memperhatikan ekspektasi dari stakeholder yang berkuasa, yaitu stakeholder yang memiliki kuasa mengendalikan sumber daya yang dibutuhkan oleh perusahaan [11]. Teori stakeholder menyatakan bahwa perusahaan memiliki tanggung jawab sosial kepada lingkungan, akan dampak yang ditimbulkan oleh aktivitas perusahaan. Atas kondisi tersebut, dukungan stakeholder sangat dibutuhkan agar perusahaan dapat mempertahankan kelangsungan usahanya..

\section{Kerangka Penelitian}

Hubungan antara variabel dalam penelitian ini tergambar sebagai berikut:

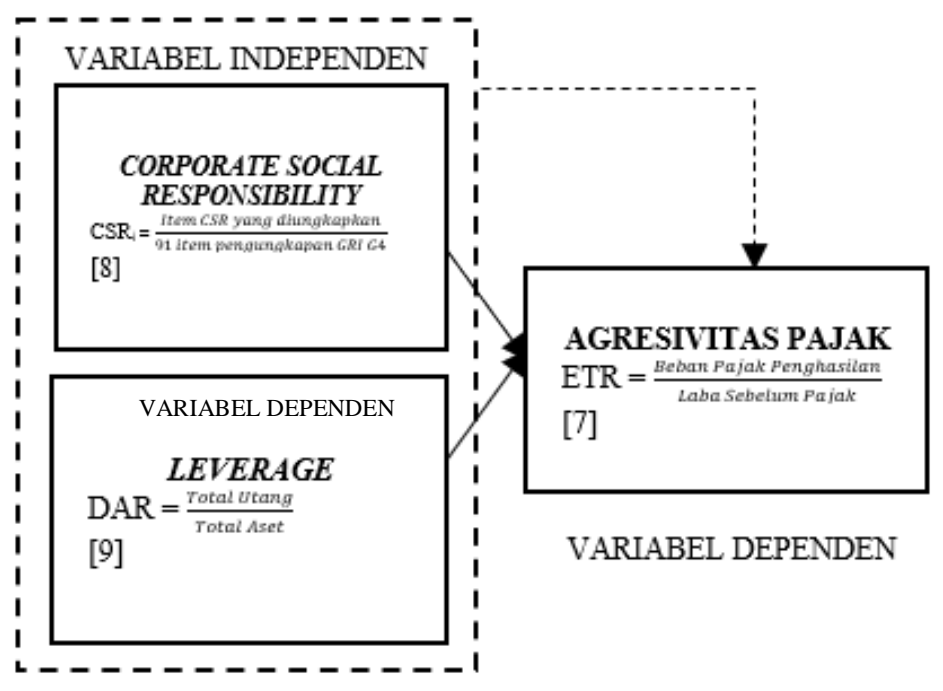

\section{Gambar 1 : Paradigma Penelitian}

\section{METODE PENELITIAN}

Data yang digunakan dalam penelitian ini adalah data sekunder yang ditarik dari website Bursa Efek Indonesia melalui www.idx.co.id. berupa Annual Report dan Laporan Keuangan Tahun 2017-2019. Jenis data penelitian merupakan data panel, dengan populasi sebanyak 45 perusahaan transportasi dan 
sampel penelitian sebanyak 33 yang terdiri dari 11 perusahan dengan tahun penelitian selama 3 (tiga) periode. Teknik penarikan sample yang digunakan adalah purposive sampling dengan kriteria sebagai berikut :

1. Perusahaan Transportasi yang terdaftar di Bursa Efek Indonesia (BEI)

2. Perusahaan transportasi yang menerbitkan laporan keuangan dan laporan tahunan serta tercatat di Bursa Efek Indonesia mulai tahun 2017-2019.

3. Perusahaan transportasi yang tidak mengalami kerugian selama kurun waktu penelitian.

Metode yang digunakan dalam penelitian ini adalah metode survey dengan pendekatan kuantitatif dengan analisis asosiatif kausalitas. Teknik analisis data yang digunakan adalah analisis regresi data panel, untuk menguji pengaruh variabel independen terhadap variabel dependen. Model persamaan dalam penelitian ini adalah:

$Y=\beta_{0}+\beta_{1} X_{i t}+\beta_{2} X_{i t}+\varepsilon$

$\mathrm{Y} \quad$ : Agresivitas pajak

$\beta_{0} \quad$ : Konstanta

$\beta_{1} \mathrm{X}_{\mathrm{it}} \quad$ : Corporate Social Responsibility

$\beta_{2} \mathrm{X}_{\mathrm{it}}$ : Leverage

$\varepsilon \quad:$ Error term

\section{HASIL DAN PEMBAHASAN}

\section{Deskripsi Sampel Penelitian}

Perusahaan yang diteliti dalam penelitian ini adalah perusahaan sektor transportasi yang terdaftar di Bursa Efek Indonesia periode 20172019. Jumlah populasi sebanyak 45 perusahaan. Adapun perhitungan sampel yang digunakan adalah sebagai berikut.

Tabel 1 : Perhitungan Sampel Penelitian

\begin{tabular}{|c|l|c|}
\hline No & \multicolumn{1}{|c|}{ Keterangan } & Jumlah \\
\hline 1 & Perusahaan transportasi yang terdaftar di Bursa Efek Indonesia. & 45 \\
\hline 2 & $\begin{array}{l}\text { Perusahaan tidak menerbitkan laporan keuangan dan laporan tahunan } \\
\text { serta tidak tercatat di BEI mulai tahun 2017-2019. }\end{array}$ & $(19)$ \\
\hline 3 & Perusahaan mengalami kerugian. & $(15)$ \\
\hline \multicolumn{2}{c}{ Perusahaan Sampel } & 11 \\
\hline Tahun Pengamatan & 33 \\
\hline
\end{tabular}

Sumber: data sekunder yang sudah diolah, 2021

Berdasarkan tabel 1, jumlah perusahaan sampel yang diperoleh sebanyak 11 perusahaan dengan 3 periode penelitian, maka jumlah sampel yang digunakan dalam penelitian sebanyak 33 sampel.

\section{Hasil Analisis Data}

\section{Analisis Statistik Deskriptif}

Analisis statistik deskriptif memberikan gambaran suatu data yang dilihat dari nilai ratarata (mean), nilai maksimum, dan nilai minimum pada setiap variabel penelitian. 


\section{Tabel 2 : Hasil Analisis Statistik Deskriptif}

\begin{tabular}{|l|l|l|l|}
\hline & \multicolumn{1}{|c|}{ ETR } & \multicolumn{1}{c|}{ CSRi } & \multicolumn{1}{c|}{ DAR } \\
\hline Min & 0.015 & 0.176 & 0.075 \\
\hline Max & 0.730 & 0.560 & 0.724 \\
\hline Mean & 0.19279 & 0.30864 & 0.41573 \\
\hline Std Dev. & 0.142352 & 0.088721 & 0.191914 \\
\hline
\end{tabular}

Sumber: data sekunder yang telah diolah dengan Microsoft Excel, 2021

Berdasarkan tabel 2, hasil analisis deskriptif untuk masing-masing variabel adalah sebagai berikut.

1. Variabel agresivitas pajak yang diproksikan dengan ETR memiliki nilai minimum sebesar 0,015 dan nilai maksimum sebesar 0,730. Nilai ETR yang semakin kecil menunjukkan perpajakan perusahaan yang semakin agresif sedangkan nilai ETR yang semakin besar menunjukkan perpajakan perusahaan yang semakin tidak agresif. Nilai rata-rata sebesar 0,19279 yang artinya rata-rata perusahaan cenderung melakukan tindakan agresivitas pajak. Nilai standar deviasi variabel ini sebesar 0,142352.

2. Variabel CSR memiliki nilai minimum sebesar 0,176 dan nilai maksimum sebesar 0,560. Nilai pengungkapan CSR yang semakin kecil menunjukkan bahwa perusahaan semakin sedikit melakukan pengungkapan CSR berdasarkan indikator GRI-G4. Nilai rata-rata sebesar 0,30864 yang artinya rata-rata perusahaan masih cenderung sedikit dalam melakukan pengungkapan CSR. Nilai standar deviasi variabel ini sebesar 0,088721 .

3. Variabel leverage memiliki nilai minimum sebesar 0,075 dan nilai maksimum sebesar 0,724. Tingkat leverage yang ideal perusahaan maksimal berada di nilai 0,5 dimana perusahaan memiliki aset dua kali lebih banyak dibandingkan kewajibannya. Nilai rata-rata atau mean sebesar 0,41573 yang artinya perusahaan sampel cenderung menggunakan utang lebih sedikit atau dalam kategori ideal. Nilai standar deviasi variabel ini sebesar 0,191914.

\section{Uji Normalitas}

\section{Tabel 3: Uji Normalitas}

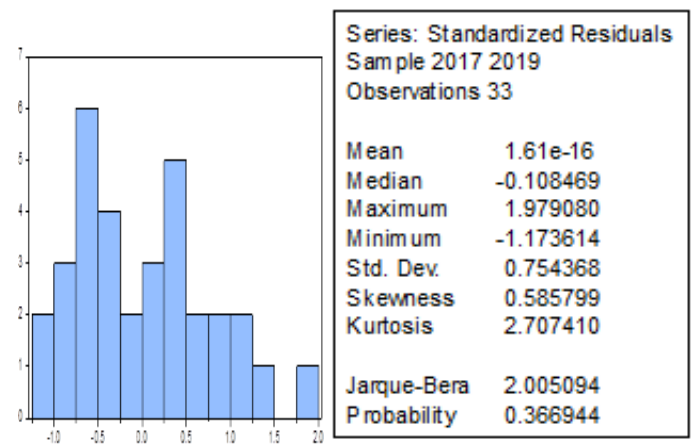

Sumber: data sekunder yang telah diolah dengan EViews 9, 2021 
Hasil dari uji normalitas menunjukkan nilai probabilitas sebesar 0,366944 dimana tingkat signifikansi >0,05. Dengan demikian, dapat disimpulkan bahwa variabel penelitian berdistribusi normal.

\section{Uji Multikolinearitas}

Tabel 4: Uji Multikolinearitas

\begin{tabular}{|ccc|}
\hline & $\mathrm{X} 1$ & $\mathrm{X} 2$ \\
\hline \hline $\mathrm{X} 1$ & 1.000000 & 0.258830 \\
$\mathrm{X} 2$ & 0.258830 & 1.000000 \\
\hline
\end{tabular}

Sumber: data sekunder yang telah diolah dengan EViews 9, 2021

Berdasarkan tabel hasil pengujian di atas, disimpulkan bahwa tidak terdapat dapat dilihat bahwa nilai tolerance antar multikolinearitas. variabel independen adalah 0,258830 dimana nilai tolerance $>0,1$ sehingga dapat

\section{Uji Heteroskedastisitas}

Tabel 5: Uji Heteroskedastisitas

Dependent Variable: RESABS

Method: Panel Least Squares

Date: 06/08/21 Time: 11:03

Sample: 20172019

Periods included: 3

Cross-sections included: 11

Total panel (balanced) observations: 33

\begin{tabular}{|c|c|c|c|}
\hline Variable & Coefficient & Std. Error & t-Statistic \\
\hline $\mathrm{C}$ & 0.048775 & 0.046166 & 1.056511 \\
\hline$X 1$ & -0.052291 & 0.140083 & -0.373283 \\
\hline $\mathrm{X} 2$ & 0.033802 & 0.064760 & 0.521954 \\
\hline
\end{tabular}

Sumber: data sekunder yang telah diolah dengan EViews 9, 2021

Berdasarkan tabel di atas, dapat dilihat bahwa model regresi dalam penelitian ini menunjukkan tidak terjadinya heteroskedas. Hal tersebut dapat dilihat dari nilai probabilitas $\mathrm{X}_{1}$ (CSR) sebesar 0,7116 dan nilai probabilitas $\mathrm{X}_{2}$ (leverage) sebesar 0,6055 dimana nilai probabilitas kedua variabel independen memiliki nilai probabilitas $>0,05$.

\section{Uji Pemilihan Estimasi Model Regresi Data} Panel

\section{Uji Chow}

Uji Chow (chow test) adalah pengujian statistik yang digunakan untuk memilih model yang paling tepat digunakan dalam estimasi data panel, apakah fixed effect atau common effect. 


\section{Tabel 6 : Hasil Uji Chow}

Redundant Fixed Effects Tests

Equation: Untitled

Test cross-section fixed effects

\begin{tabular}{|c|c|c|c|}
\hline Effects Test & Statistic & d.f. & Prob. \\
\hline & \multicolumn{3}{|c|}{$(10,20$} \\
\hline Cross-section F & 3.539047 & ) & 0.0078 \\
\hline $\begin{array}{l}\text { Cross-section Chi- } \\
\text { square }\end{array}$ & 33.616281 & 10 & 0.0002 \\
\hline
\end{tabular}

Dari tabel di atas, dapat dilihat bahwa hasil pengujian menunjukkan bahwa nilai Uji Hausman

probabilitas dari uji $\mathrm{F}$ sebesar 0,0078 dan chi-

Uji hausman adalah pengujian statistik yang square sebesar 0,0002. Dengan nilai signifikansi sebesar 0,05 dapat dikatakan bahwa probabilitas $<0,05$ dimana artinya $\mathrm{H}_{0}$ digunakan untuk memilih penggunaan model yang paling tepat untuk digunakan antara fixed ditolak dan pendekatan estimasi model yang digunakan adalah Fixed Effect Model.

Tabel 7 : Hasil Uji Hausman

Correlated Random Effects - Hausman

Test

Equation: Untitled

Test cross-section random effects

\begin{tabular}{lccc}
\hline \hline \multirow{2}{*}{ Test Summary } & \multicolumn{2}{c}{ Chi-Sq. Chi-Sq. } & \\
& Statistic & d.f. & Prob. \\
\hline \hline Cross-section random & 0.134311 & 2 & $\mathbf{0 . 9 3 5 0}$ \\
\hline \hline
\end{tabular}

Sumber: data sekunder yang telah diolah dengan EViews 9, 2021

Dari tabel di atas, dapat dilihat bahwa hasil pengujian menunjukkan bahwa nilai probabilitas sebesar 0,9350. Dengan nilai signifikansi sebesar 0,05 dapat dikatakan bahwa probabilitas $>0,05$ dimana pendekatan estimasi model yang digunakan adalah Fixed Effect Model.

\begin{abstract}
Uji Lagrange Multiplier (LM)
Lagrange Multiplier (LM) merupakan uji statistik untuk menguji apakah model yang paling tepat untuk digunakan diantara random effect dan common effect (OLS).
\end{abstract}


Tabel 8 : Hasil Uji Lagrange Multiplier (LM)

Lagrange Multiplier Tests for Random Effects

Null hypotheses: No effects

Alternative hypotheses: Two-sided (Breusch-Pagan) and one-sided (all others) alternatives

\begin{tabular}{|c|c|c|c|}
\hline & \multicolumn{3}{|c|}{ Test Hypothesis } \\
\hline & $\begin{array}{l}\text { Cross- } \\
\text { section }\end{array}$ & Time & Both \\
\hline Breusch-Pagan & $\begin{array}{l}6.782183 \\
(0.0092)\end{array}$ & $\begin{array}{l}1.500288 \\
(0.2206)\end{array}$ & $\begin{array}{l}8.282471 \\
\mathbf{( 0 . 0 0 4 0 )}\end{array}$ \\
\hline Honda & $\begin{array}{l}2.604262 \\
(0.0046)\end{array}$ & $\begin{array}{c}-1.224863 \\
--\end{array}$ & $\begin{array}{l}0.975383 \\
(0.1647)\end{array}$ \\
\hline King-Wu & $\begin{array}{l}2.604262 \\
(0.0046)\end{array}$ & $\begin{array}{c}-1.224863 \\
--\end{array}$ & $\begin{array}{c}-0.054956 \\
--\end{array}$ \\
\hline Standardized Honda & $\begin{array}{l}3.261854 \\
(0.0006)\end{array}$ & $\begin{array}{c}-0.996762 \\
--\end{array}$ & $\begin{array}{c}-1.643620 \\
--\end{array}$ \\
\hline Standardized King-Wu & $\begin{array}{l}3.261854 \\
(0.0006)\end{array}$ & $\begin{array}{c}-0.996762 \\
--\end{array}$ & $\begin{array}{c}-2.299349 \\
--\end{array}$ \\
\hline Gourierioux, et al. ${ }^{*}$ & -- & -- & $\begin{array}{l}6.782183 \\
(<0.05)\end{array}$ \\
\hline
\end{tabular}

Sumber: data sekunder yang telah diolah dengan EViews 9, 2021

Dari tabel di atas, dapat dilihat bahwa hasil pengujian menunjukkan bahwa nilai uji statistik LM sebersar 0,0040 lebih besar dari nilai statistik chi-squares sebesar 0,0002 dimana artinya $\mathrm{H}_{0}$ diterima dan pendekatan estimasi model yang digunakan adalah Common Effect

\section{Analisis Regresi Data Panel}

Berdasarkan tahapan-tahapan pengujian untuk memilih estimasi model pendekatan yang telah dilakukan, maka model pendekatan yang digunakan adalah Fixed Effect Model.

Model.

Tabel 9 : Analisis Regresi Data Panel

Dependent Variable: $Y$

Method: Panel Least Squares

Date: 06/08/21 Time: 10:22

Sample: 20172019

Periods included: 3

Cross-sections included: 11

Total panel (balanced) observations: 33

\begin{tabular}{crrrr}
\hline \hline Variable & Coefficient & Std. Error & t-Statistic & Prob. \\
\hline \hline C & -0.478200 & 0.598418 & -0.799107 & 0.4305 \\
X1 & 0.547318 & 0.499128 & $\mathbf{1 . 0 9 6 5 4 9}$ & $\mathbf{0 . 2 8 1 6}$ \\
X2 & 0.811830 & 0.237461 & $\mathbf{3 . 4 1 8 7 9 6}$ & $\mathbf{0 . 0 0 1 8}$ \\
\hline \hline
\end{tabular}

Effects Specification

Cross-section fixed (dummy variables) 


\begin{tabular}{lrlr}
\hline \hline R-squared & $\mathbf{0 . 3 5 5 8 1 4}$ & Mean dependent var & -1.973499 \\
Adjusted R-squared & 0.312868 & S.D. dependent var & 0.939891 \\
S.E. of regression & 0.779108 & Akaike info criterion & 2.425173 \\
Sum squared resid & 18.21026 & Schwarz criterion & 2.561219 \\
Log likelihood & -37.01535 & Hannan-Quinn criter. & 2.470948 \\
F-statistic & $\mathbf{8 . 2 8 5 1 9 9}$ & Durbin-Watson stat & 0.953402 \\
Prob(F-statistic) & $\mathbf{0 . 0 0 1 3 6 5}$ & & \\
\hline \hline
\end{tabular}

Sumber: data sekunder yang telah diolah dengan EViews 9, 2021

Berdasarkan data pada tabel di atas maka akan di dapatkan persamaan regresi data panel sebagai berikut:

$\mathrm{Y}=-0,478200+0,547318+0,811830+\varepsilon$

Dari persamaan regresi tersebut, dapat di analisis pengaruh variabel independent terhadap variabel dependen, yaitu:

1. Konstanta $\left(\beta_{0}\right)$ sebesar $-0,478200$ menyatakan bahwa jika nilai dari CSR dan leverage adalah nol (0), maka nilai variabel agresivitas pajak adalah sebesar 0,478200;

2. Nilai koefisien regresi dari CSR adalah sebesar 0,547318 yang artinya terdapat pengaruh positif dari variabel CSR terhadap variabel agresivitas pajak dimana setiap CSR mengalami $1 \%$ perubahan akan diikuti secara berlawanan (terbalik) terhadap agresivitas pajak sebesar $0,547318 \%$;

3. Nilai koefisien regresi dari leverage adalah sebesar 0,811830 yang artinya terdapat pengaruh positif dari variabel leverage terhadap variabel agresivitas pajak dimana setiap leverage mengalami $1 \%$ perubahan akan diikuti secara berlawanan (terbalik) terhadap agresivitas pajak sebesar $0,811830 \%$.

\section{Pengujian Hipotesis}

Uji t

Pengujian hipotesis dengan uji t dilakukan untuk menunjukan pengaruh dari variabel independen secara parsial terhadap variabel dependen. Dari hasil uji t menggunakan EViews 9 pada tabel 9 dapat dianalisis bahwa:

1. Nilai thitung dari variabel $\mathrm{X}_{1}(\mathrm{CSR})$ sebesar $1,096549<$ nilai $t_{\text {tabel }}$ sebesar 2,042 dan nilai probabilitasnya sebesar $0,2816>$ 0,05 yang artinya variabel $\mathrm{X}_{1}$ (CSR) secara parsial tidak berpengaruh signifikan terhadap variabel $\mathrm{Y}$ (agresivitas pajak).

2. Nilai $t_{\text {hitung }}$ dari dari variabel $X_{2}$ (leverage) sebesar 3,418796 > nilai $t_{\text {tabel }}$ sebesar 2,042 dan nilai probabilitasnya sebesar $0,0018<0,05$ yang artinya variabel $\mathrm{X}_{2}$ (leverage) secara parsial berpengaruh signifikan terhadap variabel Y (agresivitas pajak).

\section{Uji F}

Pengujian hipotesis dengan uji $\mathrm{F}$ dilakukan untuk menunjukan pengaruh dari variabel independen secara simultan terhadap variabel dependen. Pada tabel 9, dapat dilihat bahwa nilai probabilitas sebesar $0,001365<0,05$ dan nilai $F_{\text {hitung }}$ sebesar $8,285199>$ nilai $F_{\text {tabel }}$ 
sebesar 3,32. Hal tersebut menunjukan bahwa variabel independen secara simultan berpengaruh signifikan terhadap variabel dependen. Dengan kata lain, terdapat pengaruh secara bersama-sama secara signifikan antara CSR dan leverage terhadap agresivitas pajak.

\section{Koefisien Determinasi $\left(\mathbf{R}^{2}\right)$}

Data pada tabel 9 menunjukkan nilai $R$-squared sebesar 0,355814 atau $35 \%$. Koefisien determinasi $\left(\mathrm{R}^{2}\right)$ menunjukkan bahwa variabel $\mathrm{X}_{1}(\mathrm{CSR})$ dan $\mathrm{X}_{2}$ (leverage) secara simultan berpengaruh terhadap variabel $\mathrm{Y}$ (agresivitas pajak) sebesar $35 \%$ sedangkan $65 \%$ sisanya dipengaruhi oleh variabel lain diluar penelitian ini.

\section{Pembahasan Hasil Penelitian}

Dari hasil statistik deskriptif diketahui jumlah populasi dalam penelitian sebanyak 45 dengan perusahaan sampel sebanyak 11 perusahaan dan total sampel keseluruhan sebanyak 33 sampel. Nilai ETR perusahaan sampel memiliki nilai minimum sebesar $1,5 \%$, nilai maksimum $73 \%$ dan rata-rata $19 \%$. Hal tersebut menandakan $19 \%$ dari pendapatan sebelum pajak adalah beban pajak penghasilan perusahaan. Untuk CSRi memiliki nilai minimum sebesar $17 \%$, nilai maksimum $56 \%$ dan rata-rata $30 \%$. Hal tersebut menandakan bahwa perusahaan sudah mengungkapkan $30 \%$ dari standar pengungkapan CSR yang seharusnya. Nilai DAR perusahaan sampel memiliki nilai minimum sebesar $7,5 \%$, nilai maksimum $72 \%$ dan rata-rata $41 \%$.

\section{Pengaruh CSR terhadap agresivitas pajak}

Hasil penelitian dengan uji $\mathrm{t}$ menunjukkan bahwa CSR tidak berpengaruh terhadap agresivitas pajak. Tidak ditemukannya pengaruh antara CSR dan agresivitas pajak dapat disebabkan karena pengungkapan CSR merupakan salah satu sarana yang digunakan manajemen dalam berinteraksi dengan masyarakat dengan tujuan utama untuk mempengaruhi persepsi sedangkan agresivitas pajak sendiri bertentangan dengan harapan masyarakat. Disisi lain, di Indonesia tingkat pengungkapan CSR masih belum terperinci dan pelaksanaan program CSR setiap tahunnya pun belum konsisten serta tidak semua biaya yang dikeluarkan perusahaan untuk kegiatan CSR diakui sebagai pengurang penghasilan bruto dimana pengakuan biaya CSR sebagai pengurang penghasilan bruto dibatasi sebanyak-banyaknya $5 \%$ dari penghasilan neto fiskal tahun pajak sebelumnya. Selain itu, pelaksanaan CSR sudah di atur dalam Undangundang dimana ada sanksi yang akan diterima jika perusahaan tidak melakukannya sehingga kegiatan CSR merupakan salah satu kegiatan yang memang bersifat kewajiban.

\section{Pengaruh leverage terhadap agresivitas pajak}

Hasil penelitian dengan uji $\mathrm{t}$ menunjukkan bahwa leverage berpengaruh signifikan terhadap agresivitas pajak. Hal tersebut terjadi akibat semakin tingginya tingkat utang maka semakin tinggi pula beban bunga dan akan berdampak pada pengurangan beban pajak sebagaimana di atur dalam Undang-Undang Nomor 36 Tahun 2008 Pasal 6 ayat (1). Disisi 
lain, semakin tinggi rasio utang akan berakibat pada kemungkinan terlibatnya perusahaan dengan kendala yang ada dalam perjanjian utang yang menyebabkan besar kemungkinan terjadinya pelanggaran dalam perjanjian utang dan menimbulkan penalti. Oleh karena itu, semakin tinggi tingkat leverage perusahaan maka manajemen akan mencari yang dapat meningkatkan laba dengan tujuan untuk mengurangi penalti dalam perjanjian utang tersebut.

\section{Pengaruh CSR dan leverage terhadap agresivitas pajak}

Hasil penelitian dengan uji $\mathrm{F}$ menunjukkan bahwa CSR dan leverage memiliki pengaruh signifikan terhadap agresivitas pajak sebesar $35 \%$ pada perusahaan Transportasi yang terdaftar di Bursa Efek Indonesia (BEI) tahun 2017-2019.

\section{KESIMPULAN}

Berdasarkan hasil penelitian dari analisis yang telah dilakukan sebelumnya, maka dapat disimpulkan bahwa:

1. Corporate Social Responsibility tidak berpengaruh signifikan terhadap agresivitas pajak. Hal tersebut disebabkan tingkat pengungkapan CSR masih belum terperinci dan tidak semua biaya yang dikeluarkan untuk kegiatan CSR diakui sebagai pengurang penghasilan bruto serta biaya yang dikeluarkan pun dibatasi sebanyak-banyaknya 5\% dari penghasilan neto fiskal tahun pajak sebelumnya.
2. Leverage berpengaruh signifikan terhadap agresivitas pajak. Hal tersebut disebabkan ketika beban bunga yang berumber dari hutang dapat mengurangi beban pajak yang harus dibayar.

3. Terdapat pengaruh secara simultan dan signifikan antara Corporate Social Responsibility dan leverage terhadap agresivitas pajak dengan pengaruh sebesar $35 \%$.

\section{DAFTAR PUSTAKA}

[1] Firdayanti, N. \& Kiswanto. (2020). Pengaruh Corporate Social Responsibility dan Leverage terhadap Agresivitas Pajak dengan Komisaris Independen dan Kepemilikan Institusional sebagai Variabel Moderating, Jurnal Akuntansi, Keuangan dan Auditing Universitas Negeri Semarang Volume 1 Nomor 2.

[2] Zain, M. (2007). Manajemen Perpajakan. Jakarta: Salemba Empat.

[3] Frank, M. M. Lynch, L. J. \& Rego, S. O. (2009). Tax Reporting Aggressiveness and its relation to aggressive financial reporting, The Accounting Review. Vol 84 No 2.

[4] Yoehana, M. (2013). Analisis Pengaruh Corporate Social Responsibility terhadap Agresivitas Pajak, Semarang: Fakultas Ekonomi dan Bisnis Universitas Diponegoro.

[5] Lanis, R., Richardson, G. (2012). Corporate Social Responsibility and Tax Aggressiveness: An Empirical Analysis. Jurnal of Accounting and Economics 53.

[6] Jessica., Toly, A. (2014). Pengaruh Pengungkapan Corporate Social Responsibility terhadap Agresivitas Pajak. Tax \& Accounting Review No 4 (1). 
[7] Mustika. (2017). Pengaruh Corporate Social Responsibility, Ukuran Perusahaan, Profitabilitas, Leverage, Capital Intensity dan Kepeilikan Keluarga terhadap Agresivitas Pajak, Jurnal Fakultas Ekonomi Universitas Riau Volume 4 Nomor 1.

[8] Andhari, P. A. S. \& Sukartha, I. M. (2017). Pengaruh Pengungkapan Corporate Social Responsibility, Profitabilitas, Inventory Intensity, Capital Intensity dan Leverage pada Agresivitas Pajak, E-Jurnal Akuntansi Universitas Udayana Volume 18 Nomor 3.
[9] Kasmir. (2015). Analisis Laporan Keuangan. Jakarta: PT Raja Grafindo Persada.

[10] Gray, R. Kouhy, R. Lavers, S. (1996). Corporate Social and Environmental Report, Accounting and Auditing Journal. Vol 8, No 2, pp 4777.

[11] Deegan, C. Rankin, M. Voght, P. (2000), Firms' Disclosure Reactions to Social Incidents: Australian Evidence, Accounting Forum. Vol. 24, No. 1, pp. 120. 